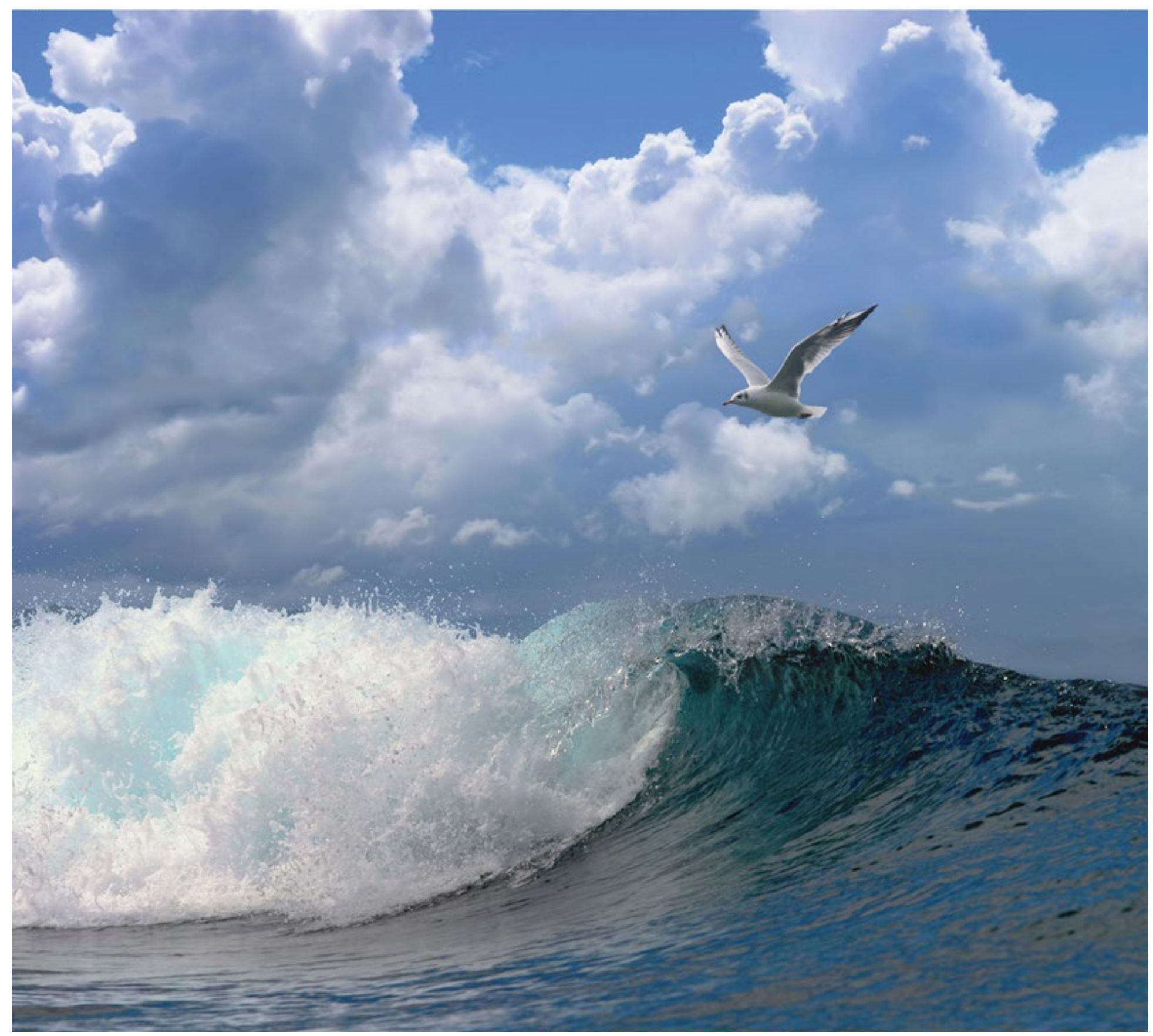

\title{
Vergelijking van dag- en nachttrekken met de boomkor in de Nederrijn
}




\section{Vergelijking van dag- en nachttrekken met de boomkor in de Nederrijn}

Auteur(s): $\quad$ T. van der Hammen, C. Chen en O. van Keeken

Publicatiedatum: 13 december 2018

Wageningen Marine Research IJmuiden, oktober 2018

Wageningen Marine Research rapport C096/18 
T. van der Hammen, C. Chen en O. van Keeken, 2018. Vergelijking van dag en nacht trekken met de Boomkor in de Nederrijn. Wageningen Marine Research rapport C096/18. 29 blz

Keywords: Nederrijn, vergelijkend vissen, dag-nacht bemonstering, boomkor, MWTL bemonstering.

Opdrachtgever: RWS

T.a.v.: Eddy Lammens

Zuiderwagenplein 2

8224 AD Lelystad

Dit rapport is gratis te downloaden van https://doi.org/10.18174/466169

Wageningen Marine Research verstrekt geen gedrukte exemplaren van rapporten.

Wageningen Marine Research is ISO 9001:2008 gecertificeerd.

\section{(C) 2018 Wageningen Marine Research}

Wageningen Marine Research, onderdeel van Stichting Wageningen Research KvK nr. 09098104,

IMARES BTW nr. NL 8113.83.696.B16. Code BIC/SWIFT address: RABONL2U IBAN code: NL 73 RABO 0373599285
De Directie van Wageningen Marine Research is niet aansprakelijk voor gevolgschade, noch voor schade welke voortvloeit uit toepassingen van de resultaten van werkzaamheden of andere gegevens verkregen van Wageningen Marine Research opdrachtgever vrijwaart Wageningen Marine Research van aanspraken van derden in verband met deze toepassing. Dit rapport is vervaardigd op verzoek van de opdrachtgever hierboven aangegeven en is zijn eigendom. Niets uit dit rapport mag weergegeven en/of gepubliceerd worden, gefotokopieerd of op enige andere manier gebruikt worden zonder schriftelijke toestemming van de opdrachtgever. 


\section{Inhoud}

$\begin{array}{lr}\text { Samenvatting } & 4\end{array}$

$1 \quad$ Inleiding $\quad 5$

2 Bemonstering en methode $\quad 6$

$\begin{array}{lll}2.1 .1 & \text { Doorzicht en temperatuur } & 7\end{array}$

$\begin{array}{lll}2.1 .2 & \text { Analyses } & 8\end{array}$

$\begin{array}{llr}3 & \text { Resultaten } & 9\end{array}$

3.1 Soortsamenstelling $\quad 9$

3.2 Biomassa per inspanning $\quad 10$

3.2.1 Alle soorten 11

3.2.2 Individuele soorten (baars, zwartbekgrondel, snoekbaars, blankvoorn en pontische stroomgrondel) 12

$\begin{array}{ll}3.3 & \text { Lengte frequentie verdeling } \\ \end{array}$

$\begin{array}{llr}\text { EKR scores } & 15\end{array}$

5 Discussie $r$

5.1 Conclusie 16

$\begin{array}{llr}6 & \text { Kwaliteitsborging } & 18\end{array}$

$\begin{array}{lr}\text { Literatuur } & 19\end{array}$

$\begin{array}{lr}\text { Verantwoording } & 20\end{array}$

$\begin{array}{llr}\text { Bijlage } 1 & \text { Plots per soort } & 21\end{array}$ 


\section{Samenvatting}

Rijkswaterstaat (RWS) heeft aan Wageningen Marine Research (WMR) gevraagd om in de Nederrijn de vangsten van een boomkorbemonstering overdag te vergelijken met de vangsten 's nachts. De achterliggende reden is dat het doorzicht van het water de vangstefficiëntie van de boomkor negatief zou kunnen beïnvloeden, waardoor overdag de vangsten lager zouden kunnen zijn in vergelijking tot 's nachts. De bemonstering, die is uitgevoerd door ATKB, heeft eind juni plaats gevonden. Bij voorkeur was er in maart bemonsterd zodat het onderzoek gelijktijdig of kort op de reguliere bemonstering plaats zou hebben gevonden. Dit was echter niet mogelijk.

Gegevens van de bemonstering 's nachts en overdag zijn vergeleken op basis van het aantal gevangen vissoorten, de biomassa per hectare en de lengtefrequentieverdeling. De lengtefrequentie en de biomassa per hectare analyses zijn gedaan voor alle vissoorten samen en voor de vijf meest voorkomende vissoorten apart (baars, zwartbekgrondel, snoekbaars, blankvoorn en pontische stroomgrondel). Daarnaast is het effect van dag- of nachttrekken doorgerekend in EKR scores. In totaal werden 17 soorten gevangen. In de nachttrekken werden er gemiddeld per trek meer soorten vis gevangen. Ook werd er meer biomassa vis per hectare in de nachttrekken gevangen dan in de dagtrekken. Van baars, snoekbaars en pontische stroomgrondel werden 's nachts significant hogere biomassa's per hectare gevangen dan overdag. Zwartbekgrondels werden 's nachts ook meer gevangen dan overdag, maar dit resultaat was niet significant. Blankvoorn liet geen verschil zien in biomassa tussen de dag- en nachttrekken. De lengtefrequentieverdelingen van de totale vangst verschilden overdag en 's nachts, waarbij er 's nachts meer kleine (0-jarige) vis werd gevangen dan overdag. Dit was het geval voor zwartbekgrondel, snoekbaars, blankvoorn en pontische stroomgrondel. Voor baars en blankvoorn zijn er geen significante verschillen tussen de dag- en nachttrekken in de lengtefrequentieverdeling. Hoewel de EKR score van de nachttrekken iets hoger was dan die van de dagtrekken vallen beide scores in dezelfde, lage, categorie. 


\section{$1 \quad$ Inleiding}

In de Nederlandse zoete Rijkswateren vindt reguliere monitoring plaats van de visstand in het kader van de 'Monitoring Waterstaatkundige Toestand des Lands' (MWTL). Deze gegevens worden gebruikt als input voor maatlat berekeningen van de Ecologische Kwaliteits Ratio's (EKR). Mede hierom is het van belang dat de monitoring een goede weerspiegeling is van de visstand en dat de vangbaarheid van vis en de efficiëntie van het gebruikte tuig niet worden beïnvloed door veranderingen in de omgeving, zoals het doorzicht. Rijkswaterstaat wil door het uitvoeren van vergelijkende trekken meer inzicht krijgen in het verschil van de vangstefficiëntie tussen de licht- en donkerperiode. Soortgelijke projecten zijn ook al uitgevoerd op het Volkerrak (van de Wolfshaar et al. 2017) en op het IJsselmeer (de Boois et al. 2017).

Om te onderzoeken of de vangstefficiëntie van de boomkor (waarmee de MWTL bemonstering wordt uitgevoerd), overdag verschilt van 's nachts, zijn in juni 201810 vergelijkende trekken uitgevoerd. De achterliggende reden is dat het doorzicht van het water overdag de vangstefficiëntie van de gebruikte boomkor negatief kan beïnvloeden, waardoor er overdag lagere vangsten worden verwacht in vergelijking tot 's nachts.

De uitvoering van het onderzoek zou bij voorkeur plaats hebben gevonden in dezelfde periode en met hetzelfde schip en tuig als de reguliere MWTL bemonstering. Echter, de schipper van de Luctor (het schip waarmee de MWTL bemonstering wordt uitgevoerd), heeft aangegeven de bemonsteringen in de donkerperiode niet uit te kunnen voeren vanwege het werkrooster en de veiligheid. WMR heeft daarom ATKB gevraagd om de bemonsteringen zowel in de licht als in de donkerperiode uit te voeren, alsmede om voor een schip te zorgen.

De bemonsteringsgegevens zijn geanalyseerd door WMR en bestaan uit vergelijkingen van de dag en nacht bemonstering op basis van i) aantal soorten, ii) de vangst per inspanning (biomassa/ha) en iii) de lengte verdelingen. Daarnaast is de EKR-score berekend voor zowel de dag- als de nachttrekken. 


\section{Bemonstering en methode}

De bemonstering op de Nederrijn heeft plaatsgevonden op 26 en 27 juni 2018 en is uitgevoerd door ATKB. De wens vooraf was om de boomkortrekken tegelijk met MWTL bemonstering te laten plaatsvinden, zodat de resultaten gebruikt konden worden voor het evalueren van de MWTL bemonstering. Dit was echter niet mogelijk vanwege de veiligheid en het werkrooster van de bemanning van de Luctor. Vervolgens was de intentie om de bemonstering zo kort mogelijk op de reguliere MWTL bemonstering uit te voeren, namelijk tussen 5 en 16 maart 2018. Deze bemonstering was volgens planning gestart, echter de vangsten bleken zeer laag, namelijk 0-2 vissen per trek met zeer veel 0 -trekken (pers. comm. ATKB). Ook in de reguliere MWTL bemonstering die ervoor had plaatsgevonden waren de vangsten erg laag. Omdat met deze lage vangsten geen functionele analyses gedaan konden worden, is deze bemonstering vroegtijdig beëindigd. Met RWS is daarna afgesproken om in de week van 8 mei 2018 te bemonsteren. Dit ging echter niet door doordat de motor van het schip van ATKB ('de Snoek') in deze week defect was. De bemonstering werd daarna op 18-20 juni gepland. Dit ging echter ook niet door doordat de waterafvoer/waterstand in deze week omhoog ging, wat bemonstering onmogelijk maakte. Uiteindelijk vonden de boomkortrekken bijna 4 maanden na de reguliere bemonstering plaats, op 26 juni en 27 juni 2018. Op deze dagen zijn de trekken zonder problemen verlopen. De weersomstandigheden waren gunstig met weinig wind en zon. Er zijn 21 boomkor trajecten in de Nederrijn uitgevoerd (10 overdag en 11 's nachts). Doorzicht is slechts 1 maal gemeten en er is aangenomen dat deze voor de andere trekken hetzelfde is (persoonlijke communicatie ATKB). Vanwege tijdgebrek is 1 trek (bene10) niet overdag uitgevoerd. Om een goede vergelijking tussen de dag en nachtrekken te kunnen maken, is deze nachttrek niet meegenomen in de analyses. Er zijn daarom 10 vergelijkende trekken in de analyses gebruikt (Figuur 1, Tabel 1).
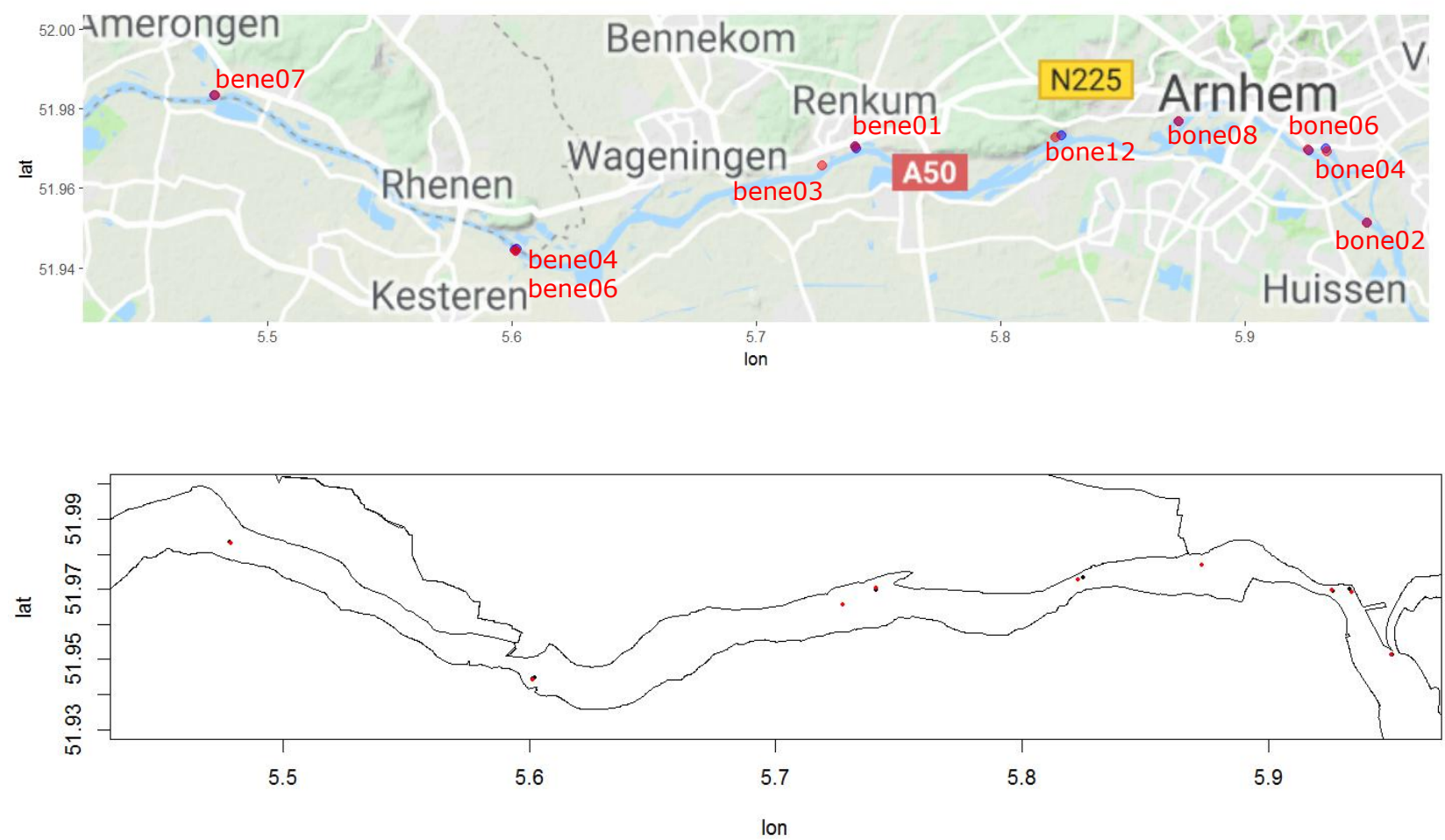

Figuur 1 Locaties van de vergelijkende trekken van de boomkor. Blauw is nacht, rood is dag. Wegens de overlap van de dag en nachtrekken en van 2 treklocaties (bene04 en bene06) is niet iedere individuele trek goed zichtbaar. Bron bovenste kaartje: Google maps. 
Tabel 1. Datum en tijdstip van de bemonstering. Trekduur is $\sim 10$ minuten. Zonsondergang op beide dagen was om 22.04. De nachttrek van bene10 is niet meegenomen in de analyses, omdat de dagtrek niet is uitgevoerd.

\begin{tabular}{c|lll} 
station & datum & tijdstip & dag/nacht \\
bene01 & $26-6-2018$ & 16.56 & dag \\
& $26-6-2018$ & 02.48 & nacht \\
bene03 & $26-6-2018$ & 17.29 & dag \\
& $26-6-2018$ & 02.13 & nacht \\
bene04 & $26-6-2018$ & 18.39 & dag \\
& $26-6-2018$ & 24.18 & nacht \\
bene06 & $26-6-2018$ & 19.13 & dag \\
& $26-6-2018$ & 24.40 & nacht \\
bene07 & $26-6-2018$ & 20.07 & dag \\
& $26-6-2018$ & 23.08 & nacht \\
bene10 & - & - & dag \\
& $26-6-2018$ & 22.43 & nacht \\
bone02 & $27-6-2018$ & 18.37 & dag \\
& $27-6-2018$ & 23.38 & nacht \\
bone04 & $27-6-2018$ & 19.18 & dag \\
& $27-6-2018$ & 22.08 & nacht \\
bone06 & $27-6-2018$ & 17.50 & dag \\
& $27-6-2018$ & 23.16 & nacht \\
bone08 & $27-6-2018$ & 17.13 & dag \\
& $27-6-2018$ & 24.01 & nacht \\
bone12 & $27-6-2018$ & 16.27 & dag \\
& $27-6-2018$ & 00.45 & nacht
\end{tabular}

\subsubsection{Doorzicht, waterdiepte en temperatuur}

De reden om verschillen in de vangsten tussen dag- en nachttrekken te onderzoeken is dat doorzicht van het water de vangstefficiëntie van de gebruikte boomkor negatief beïnvloedt. Aangezien ATKB het doorzicht niet voor alle trekken heeft gemeten kon doorzicht niet in de analyse meegenomen worden. Echter, doordat het 's nachts donker is, is het logisch dat het doorzicht 's nachts veel lager is dan overdag. Naast doorzicht was de temperatuur 's nachts ook lager dan overdag (Figuur 2a). Daarnaast was de gemiddelde diepte van de trek 's nachts enigszins lager dan overdag (Figuur 2b).

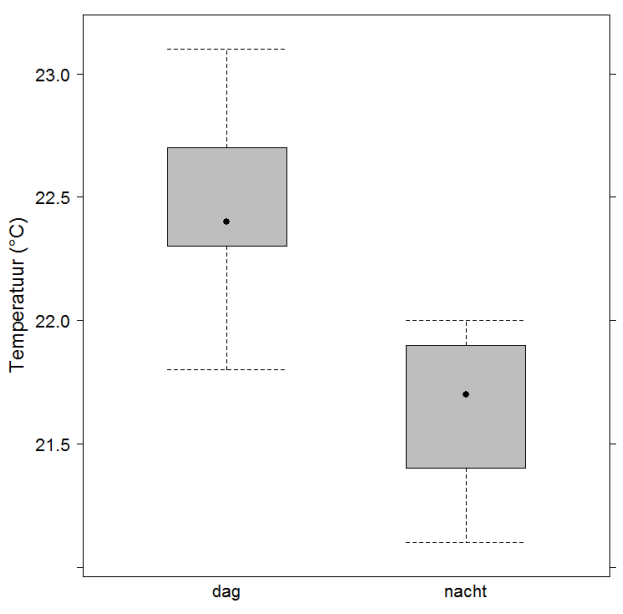

Figuur 2a Boxplot van watertemperatuur tijdens de dag- en nachttrekken.

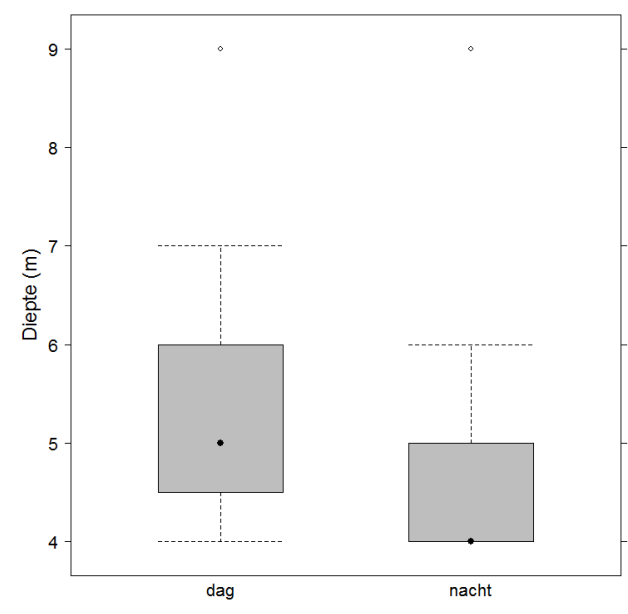

Figuur $2 \boldsymbol{b}$ Boxplot van trekdiepte tijdens de dag- en nachttrekken. 


\subsubsection{Analyses}

\section{Soortsamenstelling en biomassa per hectare}

Om de verschillen in soortensamenstelling en in biomassa per inspanning $(\mathrm{kg} / \mathrm{ha})$ te analyseren zijn zogenaamde 'Mixed Linear Models' gebruikt. Voor elke geanalyseerde locatie is er een gepaarde trek, één 's nachts en één overdag. De modellen zijn gefit met een 'restricted maximum likelihood estimation'. Effecten van de behandeling (dag of nacht) op de biomassa per inspanning werden getest met een 'Likelihood Ratio Test'. Hiervoor is de biomassa per inspanning eerst getransformeerd met een vierdemachtswortel om heteroscedasticiteit van de residuen te voorkomen.

Lengtefrequentieverdeling

Een 'niet-parametrische Kolmogorov-Smirnov two-sample' test is toegepast op de gepaarde data met de 'paired permutation' methode. Voor de analyse van de lengtefrequentieverdelingen zijn alleen de gepaarde trekken gebruikt waarvoor in beide trekken de soort gevangen was. Dit omdat van een zogenaamde nul-trek (een trek waarbij een soort niet gevangen is) geen lengtefrequentieverdeling kan worden gemaakt. 


\section{Resultaten}

\subsection{Soortsamenstelling}

Het totaal aantal gevangen vissoorten was hoger in de nachttrekken dan in de dagtrekken (Figuur 3, Figuur 4). 's Nachts werd er aal, marmergrondel, riviergrondel, sneep en winde gevangen, terwijl die overdag niet werden gevangen (Tabel 2). Overdag werd er een alver gevangen die in het donker niet werd gevangen (Tabel 2). Behalve winde ( 9 trekken) en aal (4 trekken) werden de soorten die alleen in de nacht- of dagtrekken werden gevangen slechts in 1 of 2 trekken gevangen. De soorten die zowel 's nachts als overdag werden gevangen, werden 's nachts in meer trekken gevangen en in grotere aantallen (Tabel 2). Het aantal soorten per trek dat overdag gevangen werd was gemiddeld 5 soorten minder dan wat er 's nachts gevangen werd (likelihood ratio test, $\mathrm{p}<0.001$ ).

Tabel 2 Aantal trekken waarin een soort is aangetroffen en totaal aantal per soort in de gehele bemonstering.

\begin{tabular}{|c|c|c|c|c|}
\hline \multirow[b]{2}{*}{ soort } & \multicolumn{2}{|c|}{ Aantal trekken met soort } & \multicolumn{2}{|c|}{ Totaal aantal per soort } \\
\hline & nacht & dag & nacht & dag \\
\hline Aal & 3 & 0 & 5 & 0 \\
\hline Alver & 0 & 1 & 0 & 1 \\
\hline Baars & 10 & 8 & 1389 & 70 \\
\hline Blankvoorn & 10 & 6 & 342 & 12 \\
\hline Brasem & 9 & 2 & 46 & 22 \\
\hline Hybride Cyprinide & 1 & 0 & 1 & 0 \\
\hline Kesslers grondel & 9 & 5 & 160 & 17 \\
\hline Kolblei & 7 & 1 & 23 & 1 \\
\hline Marmergrondel & 2 & 0 & 6 & 0 \\
\hline Pontische stroomgrondel & 10 & 6 & 248 & 27 \\
\hline Pos & 4 & 2 & 25 & 2 \\
\hline Riviergrondel & 1 & 0 & 1 & 0 \\
\hline Sneep & 1 & 0 & 1 & 0 \\
\hline Snoekbaars & 10 & 8 & 543 & 32 \\
\hline Winde & 8 & 0 & 70 & 0 \\
\hline Witvingrondel & 9 & 3 & 353 & 5 \\
\hline \multirow[t]{2}{*}{ Zwartbekgrondel } & 10 & 8 & 826 & 175 \\
\hline & \multicolumn{2}{|c|}{ Totaal aantal soorten } & \multicolumn{2}{|c|}{ Totaal aantal individuen } \\
\hline aantal & 16 & 11 & 4039 & 364 \\
\hline
\end{tabular}




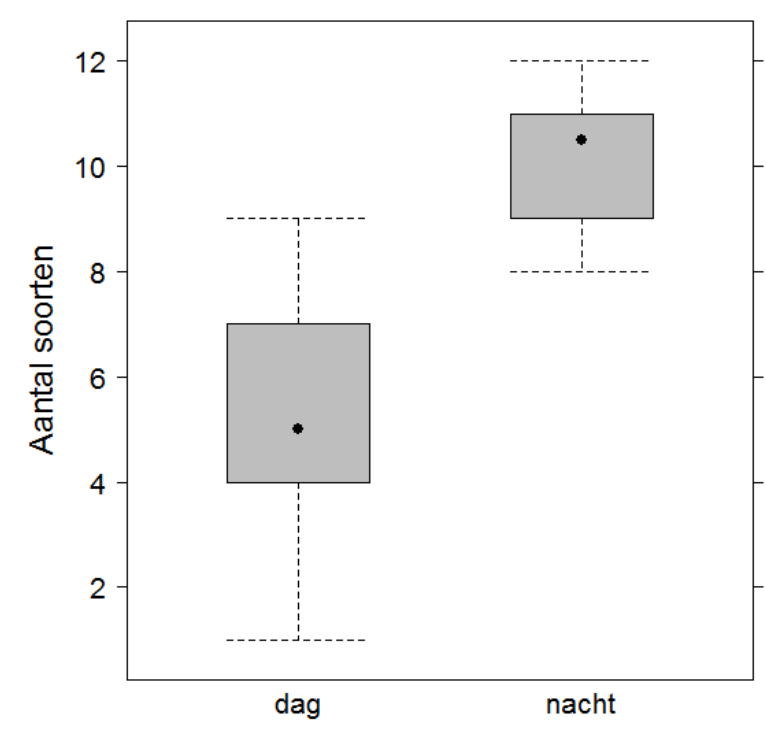

Figuur 3 Boxplot van het aantal gevangen soorten in de dag-en nachttrekken. De stip is de mediaan en de box is het eerste en derde kwartiel.

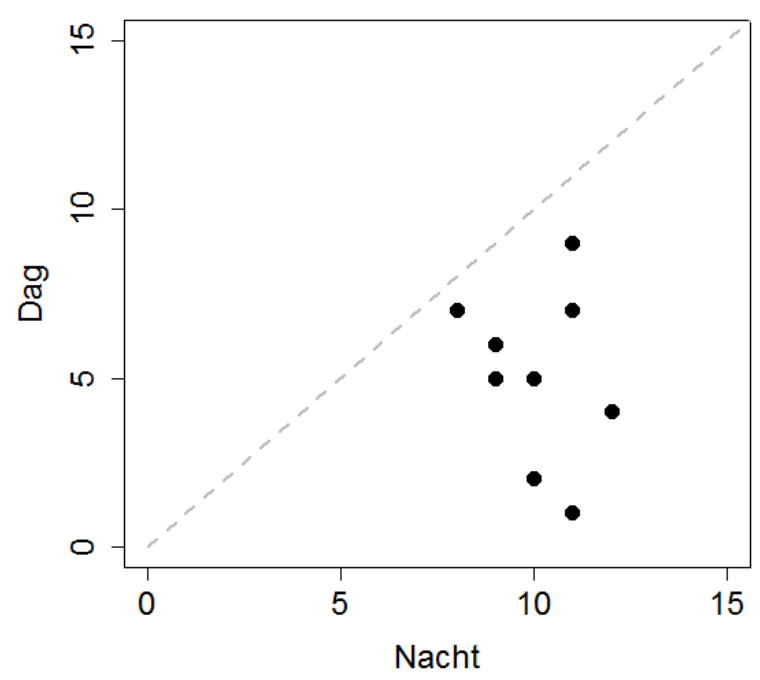

Figuur 4 Aantal soorten per trek overdag en 's nachts.

\subsection{Biomassa per inspanning (CPUE)}

Om de vergelijking te doen van de biomassa per inspanning (CPUE), zijn eerst de vangstgewichten per bevist oppervlakte (hectare) berekend. Deze zijn vervolgens getransformeerd (vierdemachtswortel) om de residuen te normaliseren. 


\subsubsection{Alle soorten}

De biomassa per hectare van alle vissoorten bij elkaar is op één locatie na altijd hoger in de nachttrekken vergeleken met de dagtrekken (Figuur 5, Figuur 6). Dit verschil is significant (likelihood ratio test, $\mathrm{p}=0.001$, Tabel 3 ).

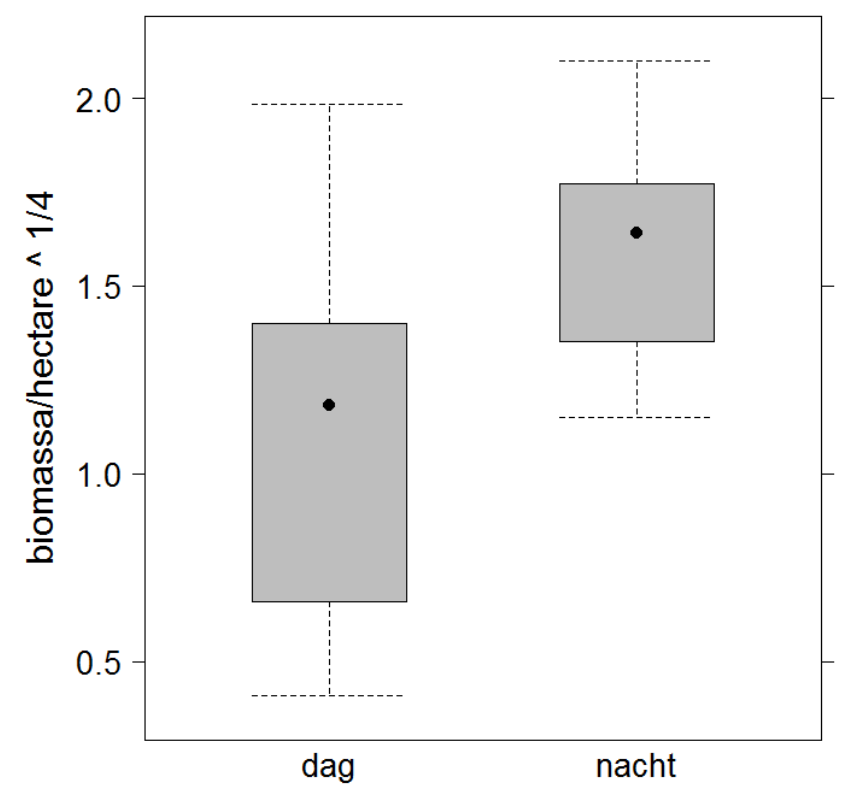

Figuur 5 Boxplot van biomassa per hectare (vierdermachtswortel getransformeerd) van alle soorten in de dag- en nachtrekken.

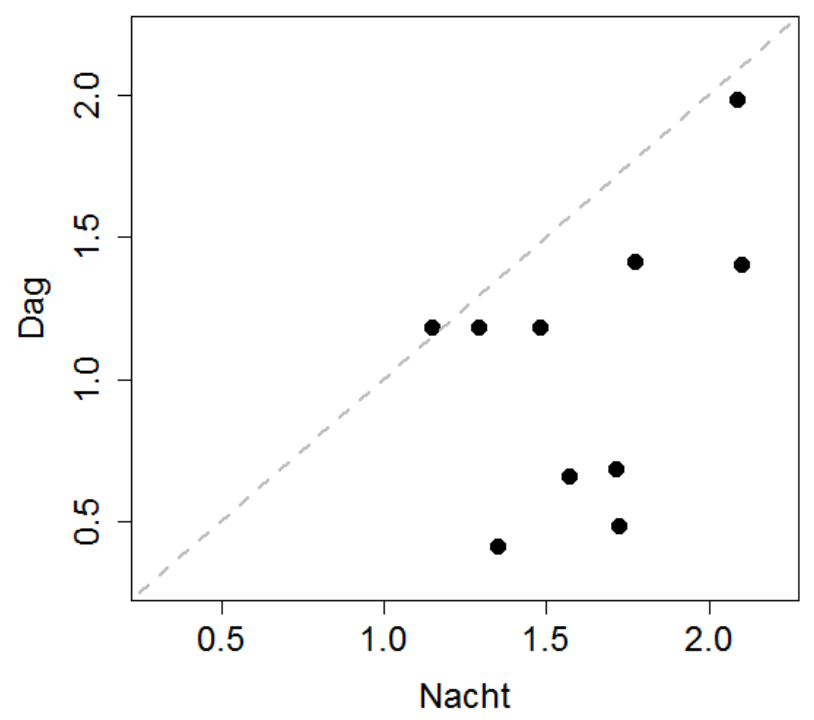

Figuur 6 Scatterplot van biomassa per hectare (vierdemachtswortel getransformeerd) van alle soorten in de dag- en nachtrekken. 


\subsubsection{Individuele soorten (baars, zwartbekgrondel, snoekbaars, blankvoorn en pontische stroomgrondel)}

De vijf soorten die in de meeste trekken waren gevangen zijn ook individueel geanalyseerd (baars, zwartbekgrondel, snoekbaars, blankvoorn en pontische stroomgrondel, Tabel 2). Voor deze soorten is gekozen omdat hierbij de minste nul-trekken waren, waardoor de kans om een effect waar te nemen het grootst is gegeven het lage aantal trekken (10 gepaarde trekken). Daarnaast is op verzoek van RWS gekeken naar brasem, kolblei en winde. Deze soorten werden in de dagtrekken veel minder gevangen dan in de nachttrekken (Tabel 2). Van de geanalyseerde vissoorten waren van baars, snoekbaars, pontische stroomgrondel, brasem, kolblei en winde de gemiddelde biomassa per hectare 's nachts significant hoger dan overdag (Tabel 3). De gemiddelde biomassa per hectare van zwartbekgrondel was ook hoger in de nachttrekken vergeleken met de dagtrekken, maar dit verschil is niet significant $(p=0.080)$. Blankvoorn vangsten waren erg scheef verdeeld over de verschillende trekken, waarbij overdag ofwel nul-trekken ofwel hoge biomassa's per hectare werden gemeten. Dit zorgde voor een gelijk gemiddelde van de dag- en nachttrekken en geen significant verschil. In Bijlage 1 staan de grafieken van de biomassa per hectare in de dag- en nachttrekken voor de geanalyseerde soorten.

Tabel 3 Samenvatting van de biomassa per hectare in de dag- en nachttrekken $(\mathrm{kg} / \mathrm{ha}$ na vierdemachtswortel transformatie) en de resultaten van de likelihood ratio test. Vetgedrukte $p$ waarden zijn significant $(p<0.05)$.

\begin{tabular}{|l|l|l|l|l|l|l|l|l|l|}
\hline & dag/nacht & min. & Q1 & mediaan & gemiddeld & Q3 & max. & trekken & p \\
\hline Alle vissoorten & nacht & 1.1 & 1.4 & 1.6 & 1.6 & 1.7 & 2.1 & 10 & $\mathbf{0 . 0 0 1}$ \\
\hline Baars & dag & 0.4 & 0.7 & 1.2 & 1.1 & 1.3 & 2.0 & 10 & \\
\hline & nacht & 0.5 & 0.7 & 0.7 & 0.8 & 0.9 & 1.3 & 10 & $\mathbf{0 . 0 0 0}$ \\
\hline Blankvoorn & dag & 0.0 & 0.3 & 0.3 & 0.4 & 0.4 & 1.1 & 10 & \\
\hline & nacht & 0.4 & 0.5 & 0.6 & 0.6 & 0.7 & 0.9 & 10 & 0.814 \\
\hline Pontische & dag & 0.0 & 0.0 & 0.8 & 0.6 & 1.0 & 1.2 & 10 & \\
\hline stroomgrondel & nacht & 0.6 & 0.7 & 0.9 & 0.9 & 1.1 & 1.1 & 10 & $\mathbf{0 . 0 0 0}$ \\
\hline Snoekbaars & dag & 0.0 & 0.0 & 0.4 & 0.3 & 0.6 & 0.8 & 10 & \\
\hline & nacht & 0.6 & 0.7 & 0.9 & 0.9 & 1.0 & 1.5 & 10 & $\mathbf{0 . 0 1 9}$ \\
\hline Zwartbekgrondel & dag & 0.0 & 0.3 & 0.5 & 0.6 & 0.6 & 1.9 & 10 & \\
\hline \multirow{2}{*}{ Brasem } & nacht & 0.6 & 0.8 & 0.8 & 0.9 & 1.0 & 1.1 & 10 & 0.080 \\
\hline & dag & 0.0 & 0.4 & 0.8 & 0.6 & 1.0 & 1.1 & 10 & \\
\hline Kolblei & nacht & 0.0 & 0.4 & 0.8 & 0.9 & 1.4 & 1.5 & 10 & $\mathbf{0 . 0 0 2}$ \\
\hline & dag & 0.0 & 0.0 & 0.0 & 0.1 & 0.0 & 0.9 & 10 & \\
\hline Winde & nacht & 0.0 & 0.2 & 1.1 & 0.8 & 1.2 & 1.6 & 10 & $\mathbf{0 . 0 0 2}$ \\
\hline & dag & 0.0 & 0.0 & 0.0 & 0.1 & 0.0 & 0.9 & 10 & \\
\hline & nacht & 0.0 & 0.3 & 0.4 & 0.3 & 0.4 & 0.4 & 10 & $\mathbf{0 . 0 0 0}$ \\
\hline & dag & 0.0 & 0.0 & 0.0 & 0.0 & 0.0 & 0.0 & 10 & \\
\hline
\end{tabular}

\subsection{Lengtefrequentieverdeling}

De lengtefrequentieverdeling in aantallen (som van aantal/hectare) laat zien dat de meeste gevangen vis in zowel de dag- als de nachttrekken uit kleine vis bestaat $(<15 \mathrm{~cm})$ en dat er erg weinig grote vis is gevangen. De kleine vis wordt in de nachttrekken duidelijk meer gevangen dan in de dagtrekken (Figuur 7). De lengte frequentieverdeling in gewichten (som van gram/hectare) laat zien dat er in de nachttrekken ook meer gewicht aan grote vis werd gevangen (Figuur 8). Dit zijn echter lage aantallen. Bijvoorbeeld, de piek in de dagtrekken bij $12000 \mathrm{gram} / \mathrm{hectare}$ wordt veroorzaakt door 1 grote snoekbaars van $63 \mathrm{~cm}$ (Figuur 8). De cumulatieve lengte verdeling (Figuur 9) laat ook zien dat de 
lengtefrequentieverdeling verschilt tussen dag en nacht, waarbij er meer kleine vis wordt gevangen in de nacht.

Voor de vergelijking van de lengte frequentieverdeling is een 'niet-parametrische gepaarde Kolmogorov-Smirnov' test gebruikt (KS-test), welke het verschil in twee verdelingen toetst. De KStest toont aan dat op basis van alle vis de lengtefrequentieverdeling (in aantallen) in de nachttrekken significant verschilt van de dagtrekken $(p<0.0001$, Tabel 4, Figuur 7$)$.

De lengtefrequentieverdeling verschilt ook significant voor de meeste geanalyseerde soorten (zwartbekgrondel, snoekbaars, blankvoorn en pontische stroomgrondel), waarbij in alle gevallen bij de nachttrekken hogere percentages kleine vis zijn gevangen. Dit verschil is vooral voor blankvoorn zeer groot, waarbij in de nachttrekken slechts 2 van 23 gevangen blankvoorns groter waren dan $5 \mathrm{~cm}$ en in de dagtrekken juist geen kleine exemplaren werden gevangen. Voor baars was er geen verschil in de lengtefrequentieverdeling tussen de nacht- en dagtrekken. De kleine vis betreft de huidige jaarklasse (0-jarigen). Doordat de bemonstering na de paai heeft plaatsgevonden, worden deze 0-jarigen ook gevangen. Indien de bemonstering tijdens de reguliere MWTL bemonstering was uitgevoerd, zouden deze niet zijn gevangen, omdat deze bemonstering voor de paai plaatsvindt. Figuren van de lengtefrequentieverdelingen van individuele soorten staan in bijlage 1. Van brasem, winde en kolblei is er geen statistische analyse op de lengtefrequentieverdeling gedaan, omdat er te weinig van is gevangen in de dagtrekken (Tabel 2).

Tabel 4 Samenvatting van de lengtefrequentieverdeling tussen de dag- en nachttrekken en de resultaten van de 'niet-parametrische Kolmogorov-Smirnov two-sample test'. Vetgedrukte $\mathrm{p}$-waarden zijn significant.

\begin{tabular}{|c|c|c|c|c|c|c|c|c|c|}
\hline & dag/nacht & $\min$. & Q1 & mediaan & gemiddeld & Q3 & $\max$ & trekken & $\mathrm{p}$ \\
\hline \multirow[t]{2}{*}{ Alle soorten } & nacht & 1.3 & 4.0 & 5.0 & 5.5 & 6.0 & 69.0 & 20 & 0.000 \\
\hline & dag & 2.1 & 5.0 & 7.1 & 7.7 & 8.7 & 63.0 & 20 & \\
\hline \multirow[t]{2}{*}{ Baars } & nacht & 3.0 & 4.0 & 5.0 & 4.8 & 5.0 & 15.0 & 16 & 1.000 \\
\hline & dag & 4.0 & 4.0 & 5.0 & 5.1 & 5.0 & 23.0 & 16 & \\
\hline \multirow[t]{2}{*}{ Blankvoorn } & nacht & 4.0 & 4.0 & 5.0 & 4.6 & 5.0 & 19.0 & 12 & 0.000 \\
\hline & dag & 15.0 & 17.8 & 18.5 & 19.9 & 21.0 & 31.0 & 12 & \\
\hline \multirow{2}{*}{$\begin{array}{l}\text { Pontische } \\
\text { stroomgrondel }\end{array}$} & nacht & 2.6 & 7.6 & 8.4 & 8.6 & 9.6 & 13.6 & 12 & 0.005 \\
\hline & dag & 7.7 & 8.5 & 9.0 & 9.0 & 9.4 & 11.0 & 12 & \\
\hline \multirow[t]{2}{*}{ Snoekbaars } & nacht & 4.0 & 6.0 & 7.0 & 7.4 & 7.0 & 48.0 & 16 & 0.000 \\
\hline & dag & 5.0 & 7.0 & 8.0 & 10.8 & 10.0 & 63.0 & 16 & \\
\hline \multirow[t]{2}{*}{ Zwartbekgrondel } & nacht & 2.0 & 3.0 & 3.4 & 4.4 & 6.0 & 13.0 & 16 & 0.000 \\
\hline & dag & 2.1 & 7.0 & 7.5 & 7.6 & 8.6 & 12.2 & 16 & \\
\hline
\end{tabular}



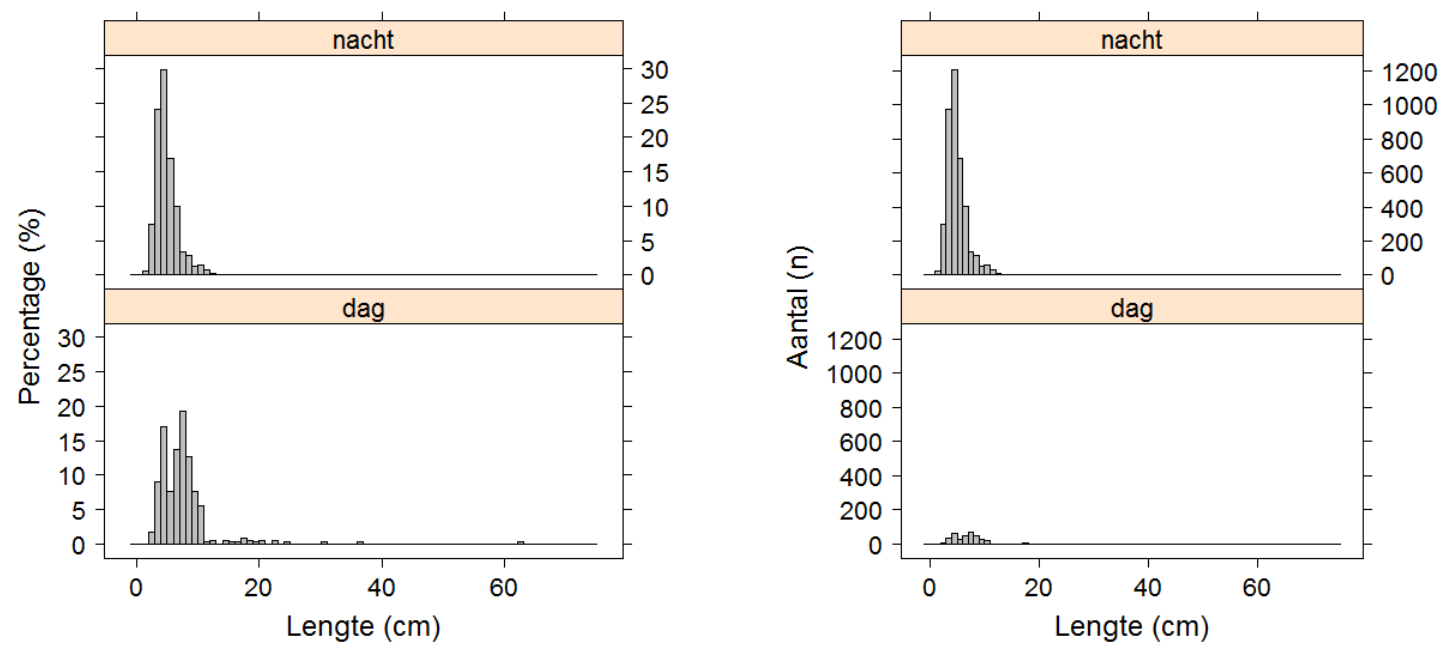

Figuur 7 Lengte verdeling voor de dag en nachttrekken (alle vis gezamenlijk). Links in percentages; rechts in aantallen (som van aantal/ha over alle trekken).
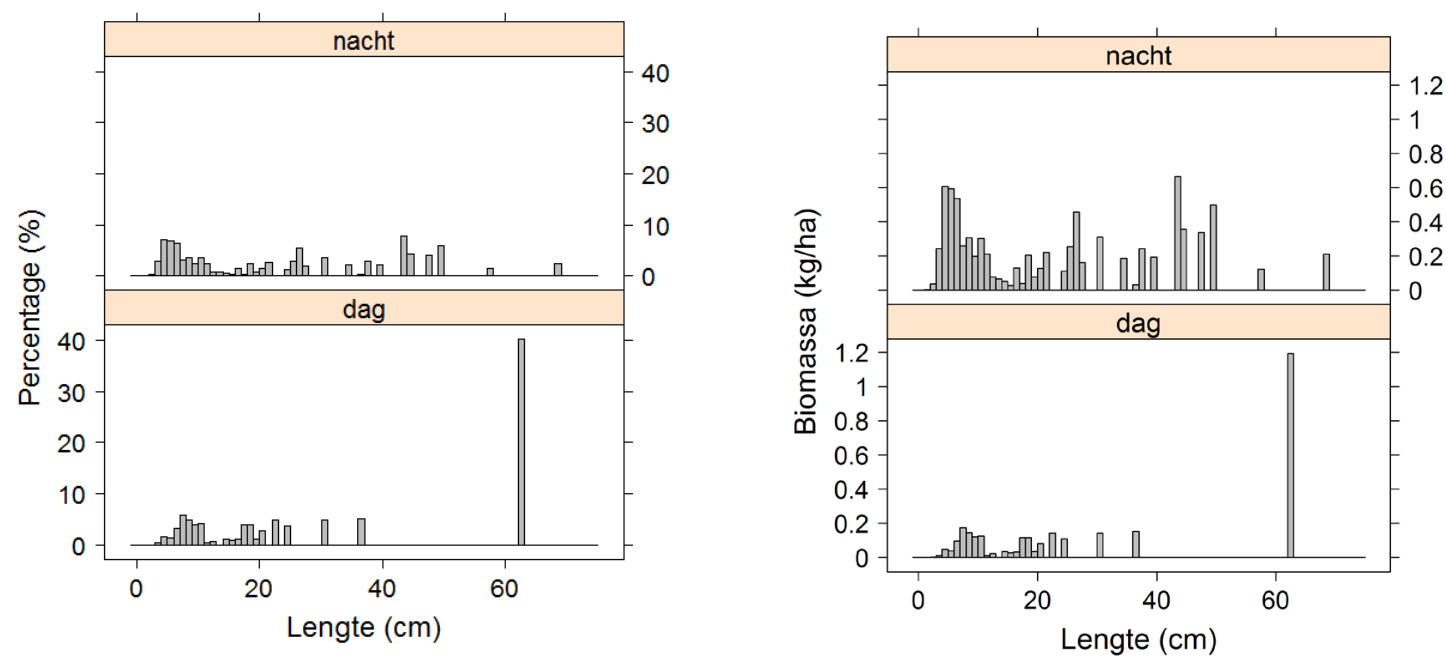

Figuur 8 Lengte verdeling voor de dag en nachttrekken (alle vis gezamenlijk). Links in percentages van cpue in gewicht ( $\mathrm{kg} / \mathrm{hectare);} \mathrm{rechts} \mathrm{in} \mathrm{gewicht} \mathrm{(gemiddelde} \mathrm{van} \mathrm{kg} / \mathrm{hectare}$ over alle trekken).
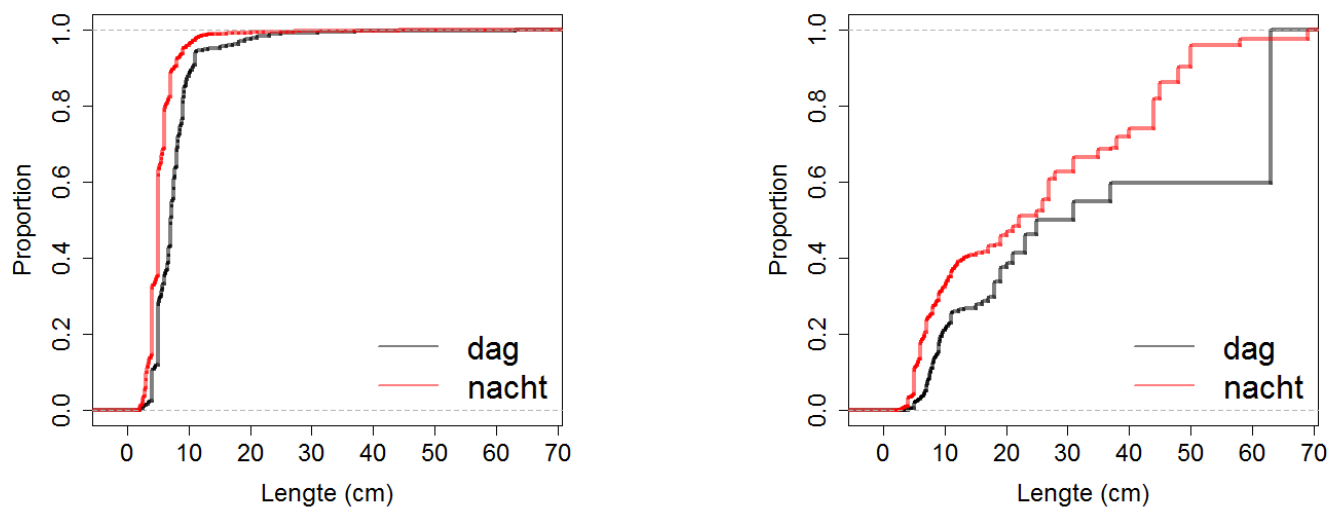

Figuur 9 Cumulatieve lengte verdeling voor de dag en nachttrekken in aantallen (links) en in biomassa (rechts). Alle vis gezamenlijk). 


\section{$4 \quad$ EKR scores}

De EKR- scores (Ecologische Kwaliteitsratio scores) zijn berekend in aquokit voor de dag- en de nachttrekken in de Nederrijn. De EKR-scores zijn respectievelijk 0.052 en 0.059 (Tabel 5), welke beide als "slecht" gescoord worden. Alle deelmaatlatten voor soortenrijkdom scoren laag met 0.1 (Tabel 5). Ook abundantie scoort laag, waarbij limnofiele vissen waarde 0 hebben. Het verschil in EKR-score wordt veroorzaakt door een andere waarde voor 'abundantie' en 'aandeel rheofielen'.

Tabel 5 EKR-scores

\begin{tabular}{|l|l|l|l|}
\hline & \multicolumn{1}{|c|}{ Dag } & Nacht \\
\hline Vis-kwaliteit & kwal.el. & $\mathbf{0 . 0 5 2}$ & $\mathbf{0 . 0 5 9}$ \\
\hline Vis-kwaliteit & kwal.el. & Slecht & Slecht \\
\hline --- Beoordeling deelmaatlatten en indicatoren --- & & & \\
\hline Soortensamenstelling vissen & & & 0.1 \\
\hline Soortenrijkdom Visgilde - diadrome soort rivieren (Dr) & Ind. & 0.1 & 0.1 \\
\hline Soortenrijkdom Visgilde - limnofiele soort (Li) & Ind. & 0.1 & 0.1 \\
\hline Soortenrijkdom Visgilde - rheofiele soort (Rh) & Ind. & 0.1 & 0.1 \\
\hline Abundantie vissen & Deelm. & 0.003 & 0.017 \\
\hline Soortenaandeel Visgilde - rheofiele soort (Rh) & Ind. & 0.005 & 0.034 \\
\hline Soortenaandeel Visgilde - limnofiele soort (Li) & Ind. & 0 & 0 \\
\hline
\end{tabular}




\section{$5 \quad$ Discussie}

Het aantal vergelijkende trekken is laag (10), waardoor niet voor alle individuele soorten een vergelijking van de biomassa per hectare gemaakt is. Los van het aantal trekken is het voor een statistische analyse noodzakelijk dat de betreffende soort in de vangst wordt aangetroffen en dat deze in voldoende mate voorkomt.

Doordat het onderzoek 4 maanden na de reguliere MWTL bemonstering heeft plaatsgevonden, is er veel kleine 0 -jarige vis gevangen welke in de reguliere bemonstering niet wordt gevangen omdat deze voor de paai plaatsvindt. Doordat er weinig grote vis is gevangen in zowel de dag- als nachttrekken, zijn de onderzoeksresultaten beïnvloed door deze 0 -jarigen. Er werd echter wel meer grote vis gevangen in de nachttrekken.

De belangrijkste resultaten van het onderzoek zijn:

- $\quad$ In de nachttrekken werden gemiddeld meer soorten per trek gevangen dan in de dagtrekken.

- In de nachttrekken werd significant meer biomassa per hectare vis gevangen dan in de dagtrekken. Er werd 's nachts ook meer kleine (0-jarige) vis gevangen dan overdag.

- In de nachttrekken werd meer biomassa per hectare baars, snoekbaars en pontische stroomgrondel gevangen dan in de dagtrekken. Van baars en snoekbaars werd er nachts vooral meer kleine vis gevangen dan overdag. Zwartbekgrondels werden 's nachts ook meer gevangen dan overdag, maar dit resultaat was niet significant. Blankvoorn liet geen verschillen zien in biomassa per hectare tussen dag en nacht.

- De EKR-score is laag voor zowel de nachttrekken als de dagtrekken. De EKR-scores voor de nachttrekken zijn iets hoger dan die van de dagtrekken.

\subsection{Conclusie}

Op basis van de huidige gegevens zijn er duidelijke verschillen tussen de boomkor bemonsteringen overdag en 's nachts. 's Nachts werden er meer soorten gevangen en de biomassa per hectare was hoger. Het resultaat wordt mede veroorzaakt doordat er 's nachts meer kleine (0-jarige) vis werd gevangen. Ook werd er meer grote vis gevangen. De grens in lengte tussen 0 -jarige vis en meerjarige vis verschilt per soort, waardoor er niet eenduidig kan worden gesteld welke vis 0-jarig en welke vis meerjarig is. Het is daardoor ook niet duidelijk of er ook een significant verschil zou zijn gevonden wanneer alleen meerjarige vis zou zijn geanalyseerd. Het is onduidelijk waarom er 's nachts juist meer 0 -jarige vis wordt gevangen. Mogelijk zitten ze 's nachts dichter bij de bodem doordat ze niet op plankton foerageren vanwege te weinig doorzicht. Indien de survey zou zijn uitgevoerd tijdens of vlak na de reguliere MWTL survey, welke voor de paai wordt uitgevoerd, dan zouden er geen vangsten van 0 -jarige vis zijn. De resultaten uit dit onderzoek zouden daardoor ten tijde van de reguliere bemonstering mogelijk anders zijn geweest.

De verschillen tussen dag en nacht zouden kunnen komen door een verschil in doorzicht, maar ook door andere factoren die 's nachts verschillen met overdag. Er kan daardoor niet worden geconcludeerd dat de gevonden verschillen door doorzicht komen. 


\subsection{Aanpassen van de bemonsteringsmethodiek}

Er zijn duidelijke verschillen gevonden tussen de dag en de nachttrekken. Ook in vorige rapportages in het Volkerak (van de Wolfshaar et al., 2017) en het IJsselmeer (de Booijs et al.,2017) zijn verschillen tussen bemonstering 's nachts en bemonstering overdag gevonden. In het Volkerak was de CPUE van snoekbaars en brasem 's nachts hoger dan overdag en in het IJsselmeer was voor pos de CPUE 's nachts hoger in vergelijking tot overdag. Van alle soorten bij elkaar werd er zowel in het Volkerak als in het IJsselmeer 's nachts iets meer vis gevangen dan overdag, echter deze verschillen waren niet significant. Het aantal trekken was in beide studies echter laag, vergelijkbaar met de huidig studie, waardoor een ander beeld had kunnen ontstaan wanneer er meer bemonsterd was.

Een vergelijking van bemonsteringstijdstip leidt tot de vraag welke methodiek het meest geschikt is voor een reguliere bemonsering. De belangrijkste afwegingen hierbij zijn 1) welke bemonstering de populatieopbouw het beste weergeeft en 2 ) welke bemonstering trends in het bestand het meest betrouwbaar weergeeft. In principe kan er gesteld worden dat hoe groter de vangst hoe meer informatie er verzameld wordt en trendberekeningen dus nauwkeuriger worden. Echter, om de eerste vraag goed te kunnen beantwoorden is kennis over de echte populatieopbouw nodig. Als deze niet bekend is zal ook moeilijk geconcludeerd kunnen worden welke methodiek deze het beste benaderd. Ook zijn er verschillen per soort of locatie te verwachten, waardoor er mogelijk niet een keuze is die voor alle soorten of locaties optimaal is. Bij een eventuele aanpassing van de bemonsteringsmethodiek zullen ook praktische overwegingen moeten worden meegenomen. Daarnaast is het van belang dat de scheepvaart de veiligheid en uitvoering van het programma zo min mogelijk beïnvloedt. Wanneer er van bemonsteringmethodiek wordt veranderd, zal er ook rekening gehouden moeten worden met het ontstaan van een trendbreuk in de tijdsserie. 


\section{$6 \quad$ Kwaliteitsborging}

Wageningen Marine Research beschikt over een ISO 9001:2008 gecertificeerd kwaliteitsmanagementsysteem (certificaatnummer: 187378-2015-AQ-NLD-RvA). Dit certificaat is geldig tot 15 december 2018. De organisatie is gecertificeerd sinds 27 februari 2001. De certificering is uitgevoerd door DNV Certification B.V. 


\section{Literatuur}

De Boois, I., T. van der Hammen, C. Chen. 2017, Vergelijking van dag- en nachttrekken in de IJsselmeersurvey 2016. Wageningen Marine Research Wageningen UR (University \& Research centre), Wageningen Marine Research briefrapport CVO/1711472

Van de Wolfshaar, K.E., C. Chen en B. Griffioen. 2017. Vergelijkend vissen: dag-nacht en boomkorstortkuil in het Volkerak. Wageningen Marine Research Wageningen UR (University \& Research centre), Wageningen Marine Research rapport C048/17. 


\section{Verantwoording}

Rapport C096/18

Projectnummer: 4311100075

Dit rapport is met grote zorgvuldigheid tot stand gekomen. De wetenschappelijke kwaliteit is intern getoetst door een collega-onderzoeker en het verantwoordelijk lid van het managementteam van Wageningen Marine Research

Akkoord:

Karen van de Wolfshaar

Onderzoeker

Handtekening:

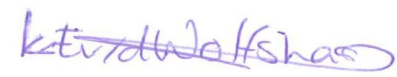

Datum:

7 december 2018

Akkoord:

Drs. J. Asjes

MT lid Integratie

Handtekening:

Datum:

13 december 2018 


\section{Bijlage 1 Grafieken per soort}

Figuur B1 De figuren hieronder zijn per soort: Linksboven: boxplots van de dag en nachtvangsten (vierdemachtswortel getransformeerd). Rechtsboven: cpue (biomassa/hectare, vierdemachtswortel getransformeerd) van dag en nachttrekken tegen elkaar uitgezet. Onder: lengteverdeling in percentage $(\mathrm{kg} / \mathrm{hectare}$, linksonder) of in biomassa (gemiddelde van $\mathrm{kg} / \mathrm{hectare}$ over alle trekken, rechtsonder).

\section{Baars}
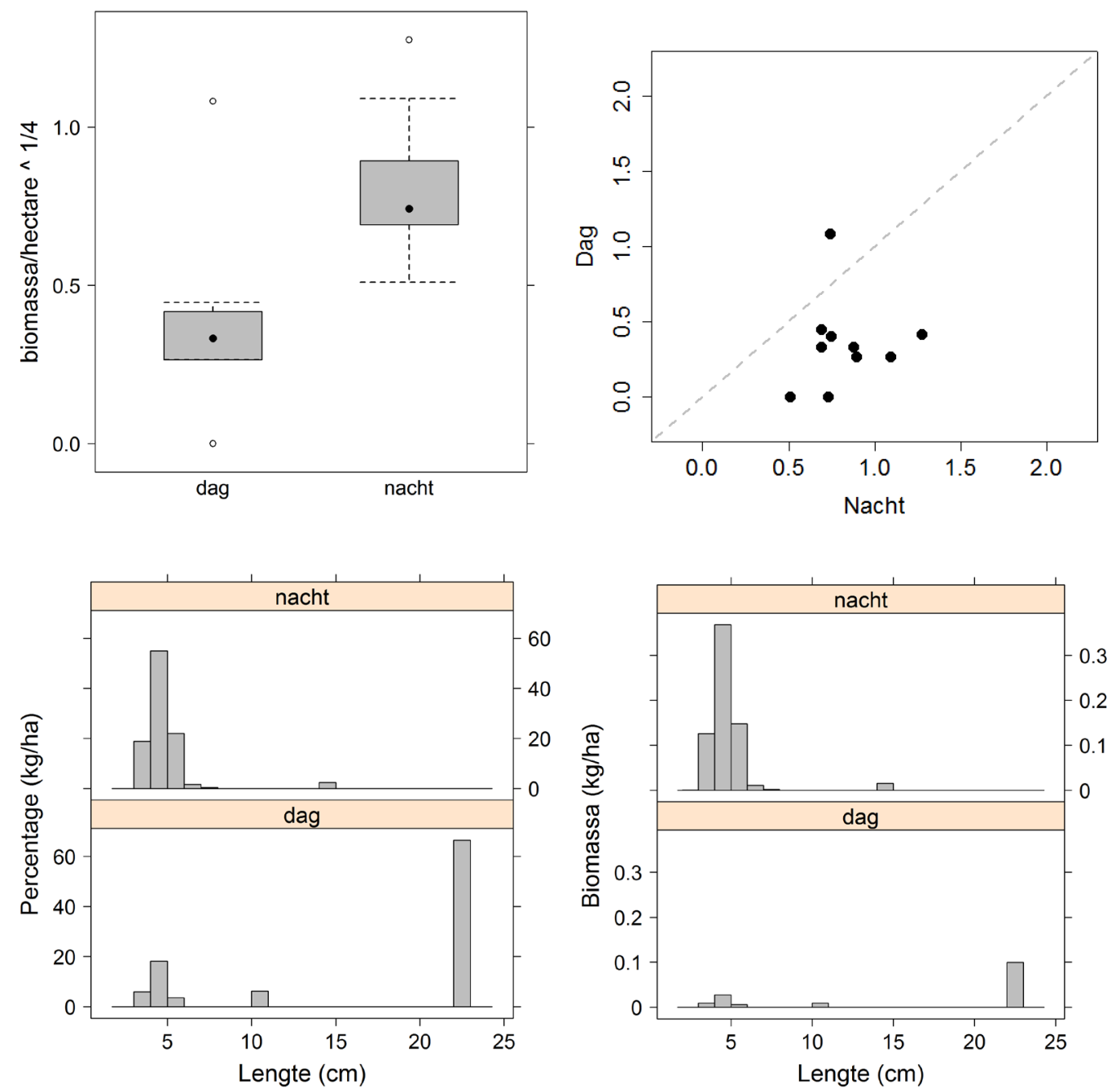
Zwartbekgrondel
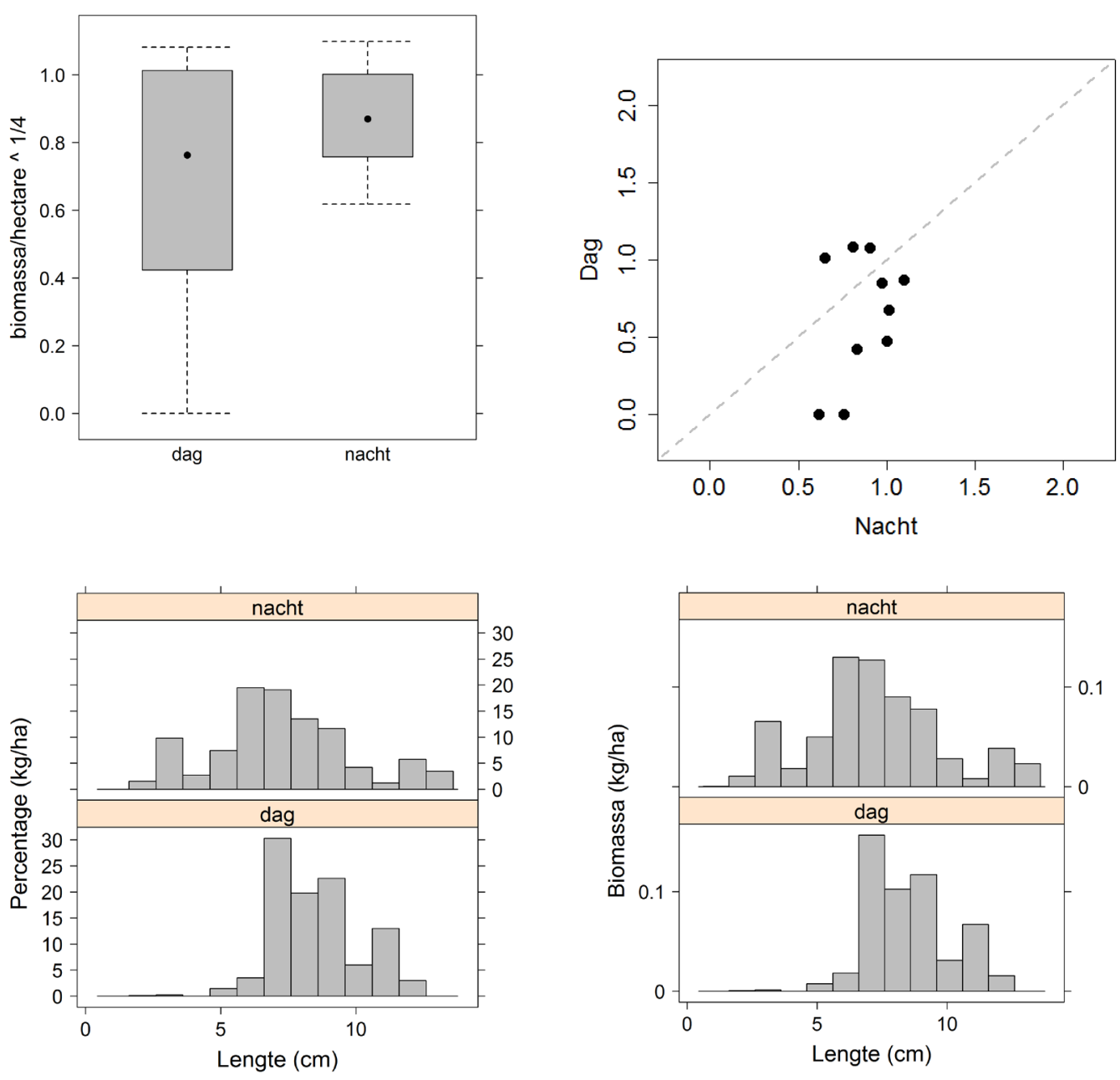


\section{Snoekbaars}
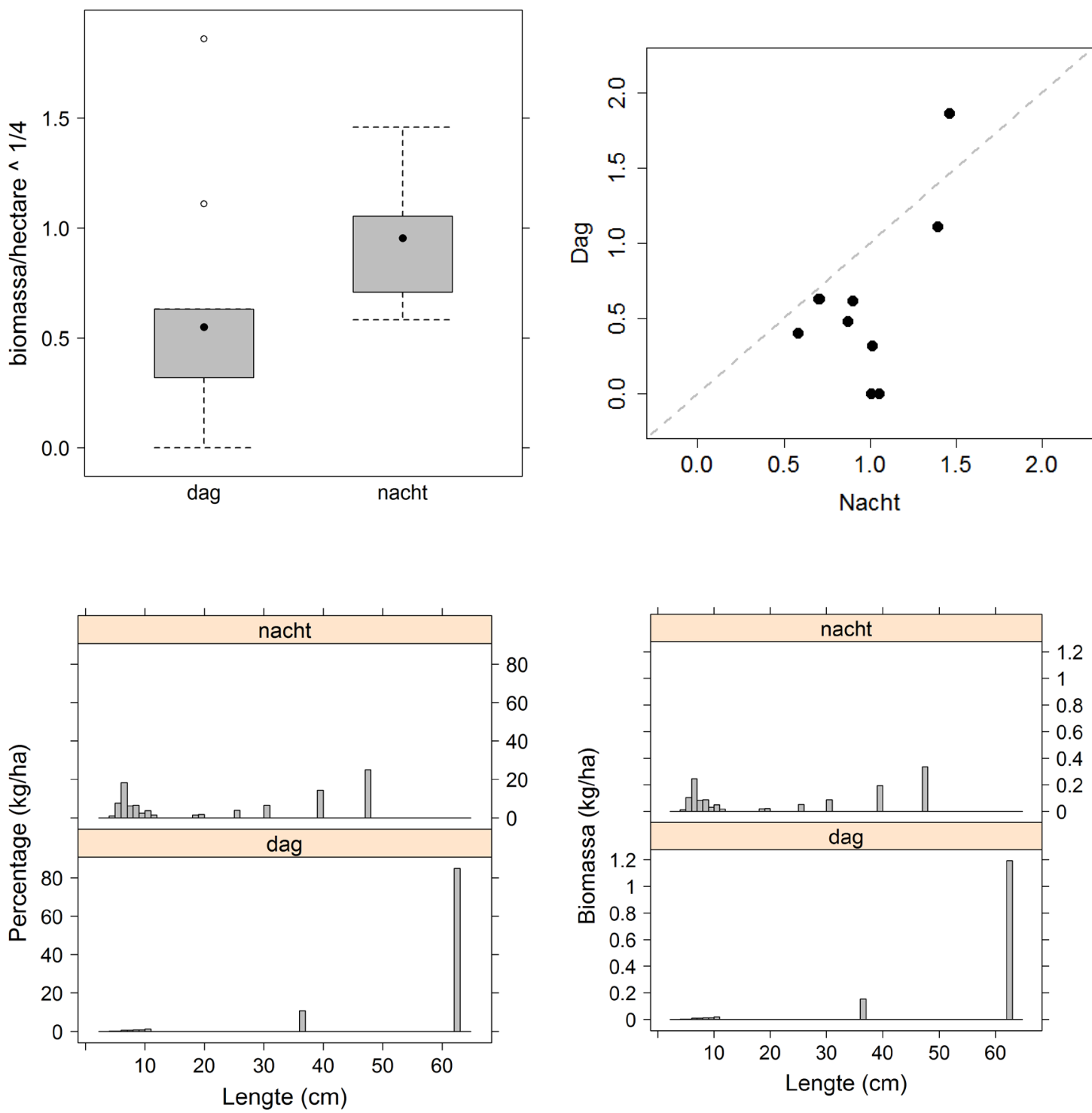
Blankvoorn
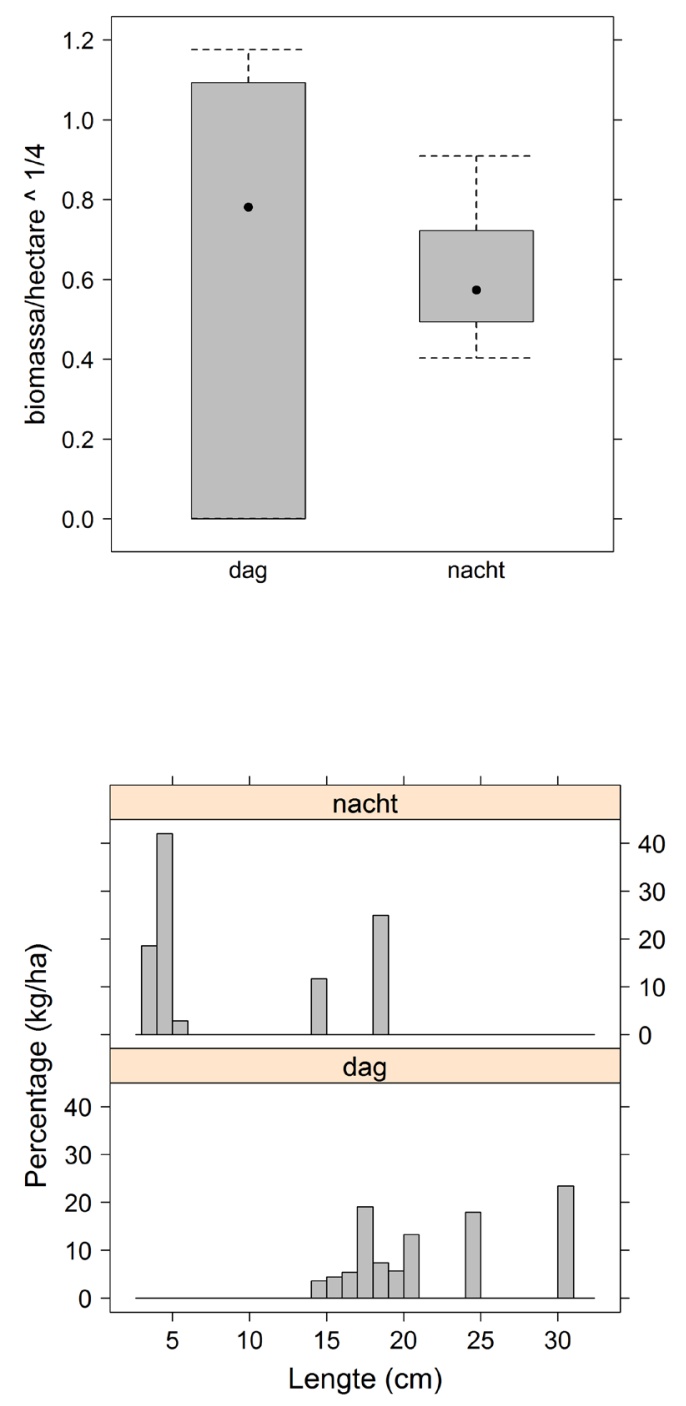
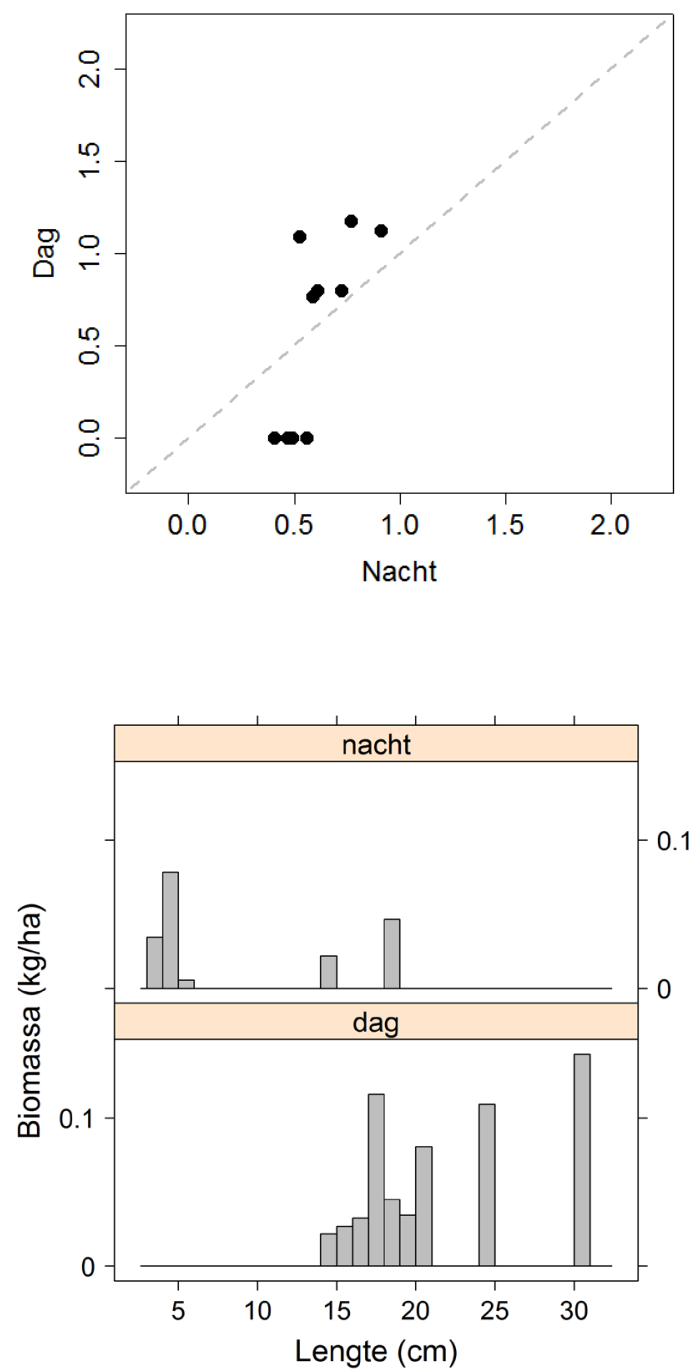


\section{Pontische stroomgrondel}
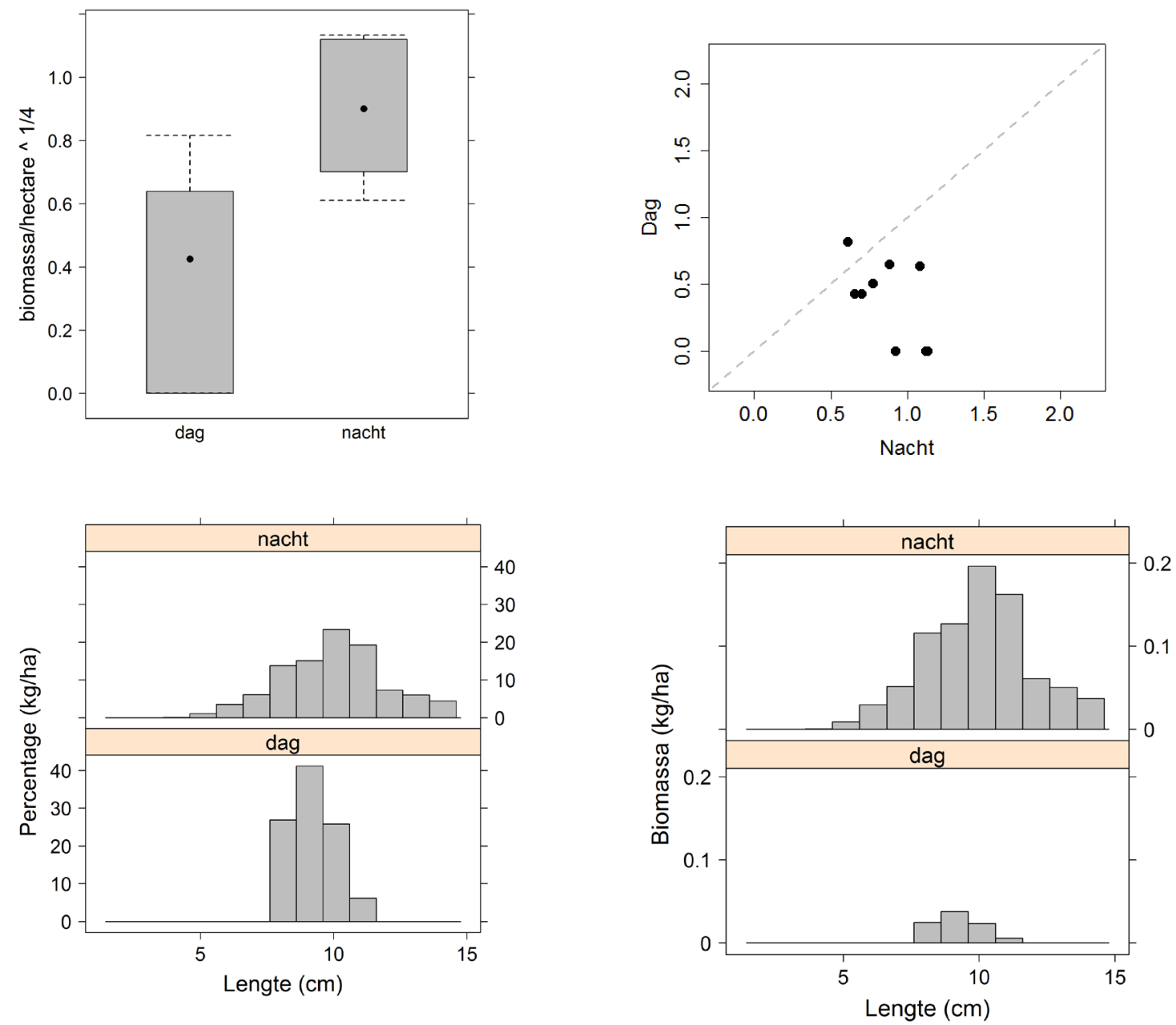


\section{Kolblei}
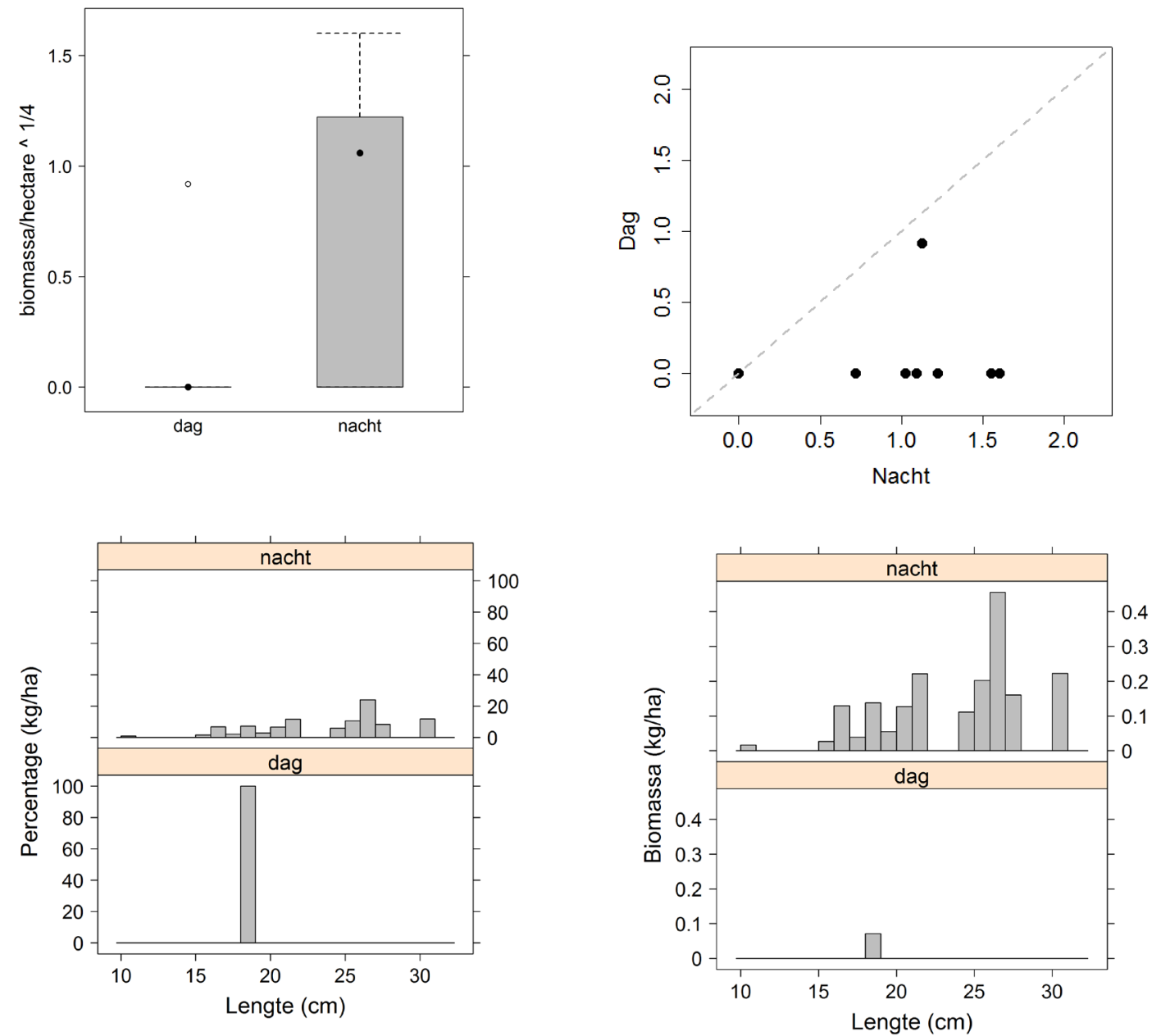


\section{Brasem}
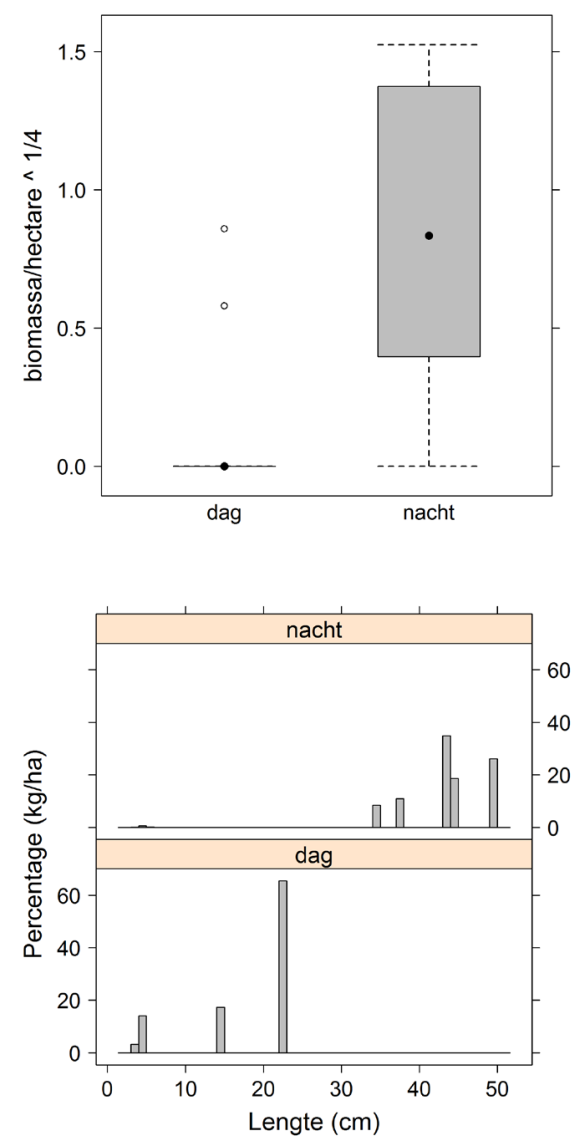
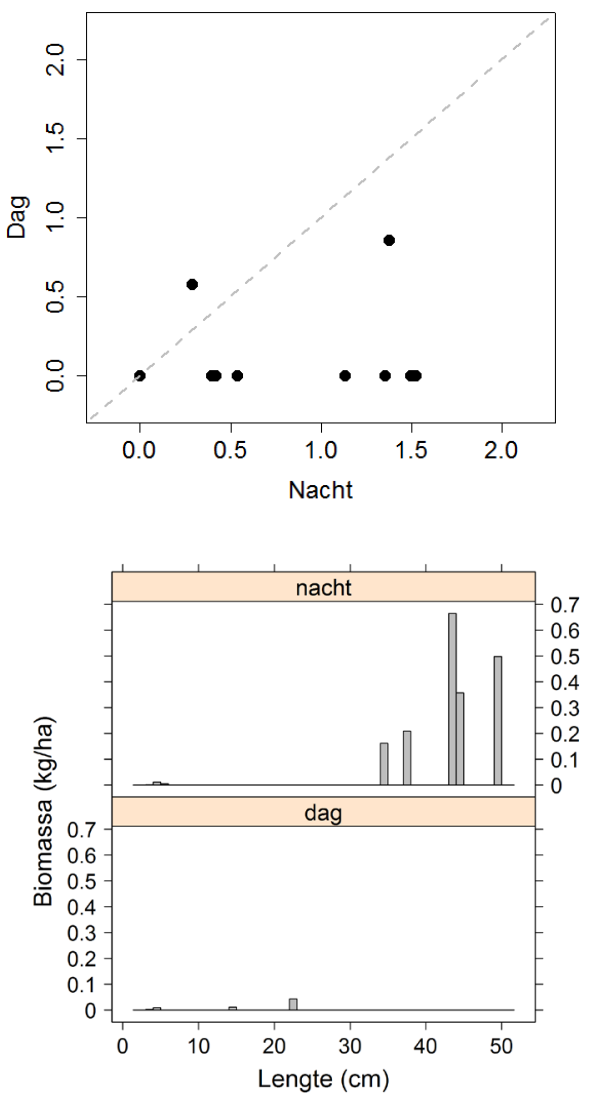
Winde
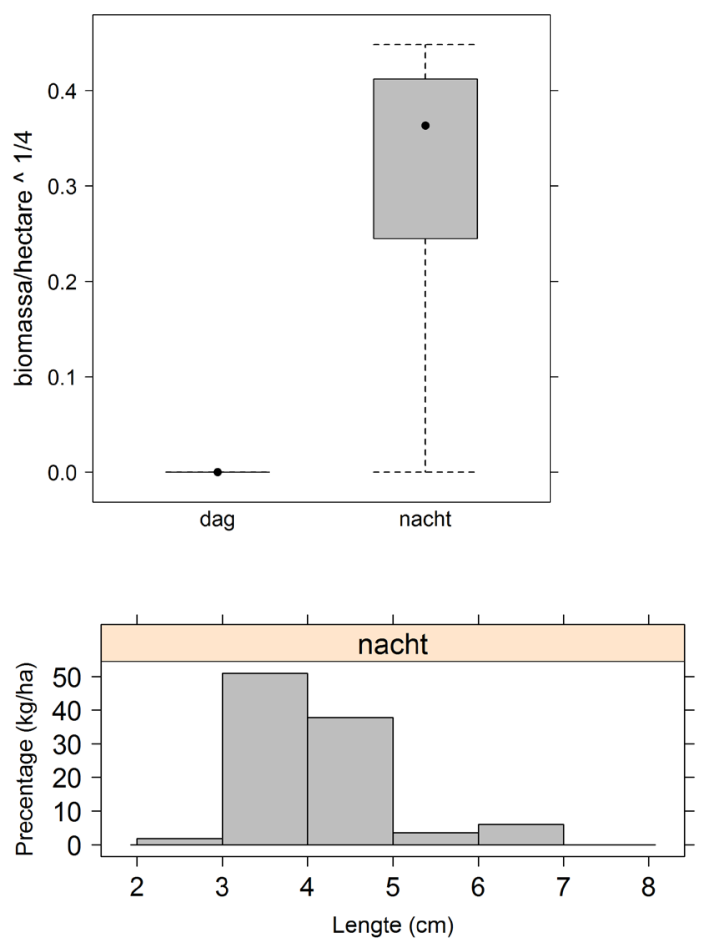
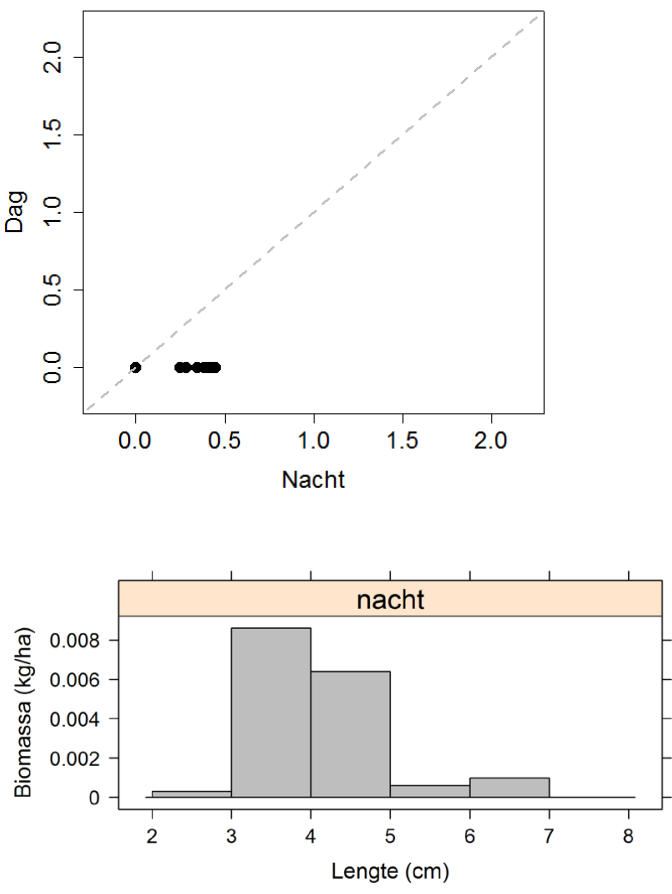
Wageningen Marine Research

T: +31 (0)317480900

E: marine-research@wur.nl

www.wur.nl/marine-research

Visitors address

- Ankerpark 271781 AG Den Helder

- Korringaweg 7, 4401 NT Yerseke

- Haringkade 1, 1976 CP IJmuiden
Wageningen Marine Research is the Netherlands research institute established to provide the scientific support that is essential for developing policies and innovation in respect of the marine environment, fishery activities, aquaculture and the maritime sector.

Wageningen University \& Research is specialised in the domain of healthy food and living environment.

The Wageningen Marine Research vision:

'To explore the potential of marine nature to improve the quality of life.'

The Wageningen Marine Research mission

- To conduct research with the aim of acquiring knowledge and offering advice on the sustainable management and use of marine and coastal areas.

- Wageningen Marine Research is an independent, leading scientific research institute.

Wageningen Marine Research is part of the international knowledge organisation Wageningen UR (University \& Research centre). Within Wageningen UR, nine specialised research institutes of Stichting Wageningen Research (a Foundation) have joined forces with Wageningen University to help answer the most important questions in the domain of healthy food and living environment. 